Csedő Zoltán - Pörzse Gábor - Zavarkó Máté

\title{
AZ INNOVÁCIÓS TUDÁSHÁLÓZATOK A FELSÖOKTATÁSBAN: EGY POWER-TO-GAS INNOVÁCIÓS ÖKOSZISZTÉMA FEJLŐDÉSÉNEK TAPASZTALATAI ${ }^{1}$
}

The Role of Innovation Knowledge Networks in Higher Education: Experiences of the Development of a Power-to-Gas Innovation Ecosystem

Dr. habil. Csedő Zoltán tanszékvezető egyetemi docens, Budapesti Corvinus Egyetem, Vezetéstudományi Intézet, Vezetés és Szervezés Tanszék, zoltan.csedo@uni-corvinus.hu; ügyvezető igazgató, Power-to-Gas Hungary Kft.

Dr. Pörzse Gábor kutatóközpont vezető egyetemi magántanár, Budapesti Corvinus Egyetem, Corvinus Innovációs Kutatóközpont, gabor.porzse@uni-corvinus.hu

Zavarkó Máté doktorjelölt, Budapesti Corvinus Egyetem, Vezetéstudományi Intézet, Vezetés és Szervezés Tanszék, mate.zavarko@uni-corvinus.hu; üzletfejlesztési igazgató, Power-to-Gas Hungary Kft.

Hálózatelméleti alapokra építve, kutatásunkban azt vizsgáljuk, hogy az innovációs ökoszisztéma meghatározó hálózati csomópontjaiként milyen szerepük van a felsőoktatási intézményeknek az innovációs tudáshálózatokfejlesztésében, mivel megteremtik a kapcsolatot az elméleti alapkutatás, a gyakorlati vállalati innováció és a szabályozói intézményrendszer között. A jogalkatónak ösztönöznie kell e kulcscsomóponton áthaladó, illetve kiteljesedő tudás áramoltatását egy olyan innovációs hálózatban, amely a társadalom számára is hasznot jelent. Egy konkrét esettanulmánnyal szemléltetjük, mindez hogyan müködhet(ne) a gyakorlatban.

A szerzők ezúton mondanak köszönetet a Kutatás-fejlesztési és Innovációs Állami Tőkealap-kezelő Zrt. / Hiventures Zrt., valamint a Vértesi Erőmű Zrt. számára a K+F+I-tevékenységek megvalósításának támogatásáért. 


\section{KulcsszavaK:}

innovációs ökoszisztéma, tudáshálózat, egyetem-ipar együttmüködés, szabályozói ösztönzés

Building on the fundamentals of network theories, our research analyses the role of higher education institutions as network nodes of the innovation ecosystem that create connections among basic research, practical corporate innovation and regulatory institutions. The legislator should incite the "flow" of the evolving knowledge within an innovation network that means benefit for the society. Through a concrete case study, it is presented how these processes (could) work in practice.

\section{Keywords:}

innovation ecosystem, knowledge network, university-industry cooperation, regulatory incentive 


\section{BEVEZETÉS}

A 2020-as és 2021-es évek meghatározó témája volt a tudományos és a civil szférában is, hogy a társadalmak és a kormányok világszerte komoly egészségügyi és gazdasági kihívásokkal néztek (néznek) szembe a Covid-19-járvány miatt. Ugyanakkor, a gyors oltóanyag-fejlesztés szükségessége kutatásfejlesztési szempontból nyomást gyakorolt profitorientált és nonprofit szervezetekre is, például biotechnológiai és gyógyszeripari vállalatokra, egyetemekre vagy kutatóközpontokra. ${ }^{2} \mathrm{Az}$ emberiség e konkrét - remélhetőleg rövid távú - kihívása felhívta a figyelmet a szervezetek közötti együttműködés és a hatékony tudásátadás fontosságára, ez a fokozott figyelem pedig segíthet a hosszú távú problémák kezelésében is. Az egyik legfőbb hosszú távú kihívás a fejlett országok társadalmaira nehezedő, karbonsemleges gazdaságok létrehozására vonatkozó nyomás, amely - történelmi távlatból nézve - szintén gyors innovációt és technológiafejlesztést igényel.

A karbonsemlegességet célzó energetikai innovációk egyik speciális területe a megújuló energia hatékony, rugalmas és hosszú távú tárolásának megoldása, ${ }^{3}$ amelyet - az Európai Unió klímasemlegességet célzó stratégiájával összhangban - a növekvő volumenű és váltakozó megújuló villamosenergia-termelés okoz (hazánkban például a gyorsan növekvő fotovoltaikus kapacitások). ${ }^{4}$ Ígéretes innovációs irány ezen a területen a power-to-gas (P2G) technológiák fejlesztése és alkalmazása, amely a $\mathrm{CO}_{2}$ újrahasznosításával és a földgázhálózat meglévő kapacitásainak felhasználásával ${ }^{5}$ rugalmasságot $^{6}$ és hatékony szezonális energiatárolást ${ }^{7}$ képes biztosítani, azonban a dekarbonizációs és energiatárolási potenciál ellenére a P2G-technológiák széles körü alkalmazása még várat magára. ${ }^{8}$ A széles körü ipari alkalmazáshoz már közeli, de részben még fejlesztés alatt lévő technológia ${ }^{9}$ alacsony

2 Lawrence B. Corey et al.: A Strategic Approach to COVID-19 Vaccine R\&D. Science, 368. (2020), 6494. $948-$ 950.

$3 \quad$ Henrik Lund et al.: Energy storage and smart energy systems. International Journal of Sustainable Energy Planning and Management, 11. (2016), 3-14.

4 Aram M. Ahmed - László Kondor - Attila R. Imre: Thermodynamic Efficiency Maximum of Simple Organic Rankine Cycles. Energies, 14. (2021), 2. 307; Gábor Pintér et al.: The Economic and Geographical Aspects of the Status of Small-Scale Photovoltaic Systems in Hungary - A case study. Energies, 13. (2020), 13. 3489; László Berényi - Zoltán Birkner - Nikolett Deutsch: A Multidimensional Evaluation of Renewable and Nuclear Energy among Higher Education Students. Sustainability, 12. (2020), 4. 1449.

5 Zoltán Csedő - Máté Zavarkó: The Role of Inter-Organizational Innovation Networks as Change Drivers in Commercialization of Disruptive Technologies: The Case of Power-to-Gas. International Journal of Sustainable Energy Planning and Management, 28. (2020), 53-70.

6 Gábor Pintér: The Potential Role of Power-to-Gas Technology Connected to Photovoltaic Power Plants in the Visegrad Countries - A Case Study. Energies, 13. (2020), 23. 6408.

7 Zoltán Csedő - Botond Sinóros-Szabó - Máté Zavarkó: Seasonal Energy Storage Potential Assessment of WWTPs with Power-to-Methane Technology. Energies, 13. (2020), 18. 4973.

8 Jordi Guilera - Joan R. Morante - Teresa Andreu: Economic Viability of SNG Production from Power and CO2. Energy Conversion and Management, 162. (2018), 218-224; Ralf Peters et al.: A Techno Economic Analysis of the Power to Gas Route. Journal of CO2 Utilization, 34. (2019), 616-634.

9 Máté Zavarkó et al.: Past, Present and Near Future: An Overview of Closed, Running and Planned Biomethanation Facilities in Europe. Energies, 14. (2021), 18. 5591. 
elterjedtségi szintje és magas értékteremtési potenciálja közt a „hidat” a szervezetközi hálózatok és a tudástranszfer jelentheti a szakirodalom alapján, ugyanis

- az ilyen innovatív megoldások fejlesztése és hasznosítása érdekében több tudásés adatforrást kell szintetizálni; ${ }^{10}$

- az érintetteknek olyan szervezetközi K+F+I-együttműködéseket kell kialakítaniuk, amelyek elérhetővé teszik számukra tudományos, műszaki és gazdasági ismeretek becsatornázását is a folyamatba, ${ }^{11}$ és ez az integratív megközelítés teszi lehetővé olyan szövetségek létrehozását is, amelyek megkönnyítik a szabályozói oldal döntéshozóival történő kapcsolatteremtést; ${ }^{12}$

- a profitorientált ipari szereplők, az egyetemek és a szabályozók közötti együttmüködés egyre nagyobb szerepet játszik a társadalmi értékteremtésben és -megőrzésben, a lakossági igényekre való reagálásban és a fenntartható megoldások kialakításában is. ${ }^{13}$

E szakirodalmi eredményekre építő előfeltevések alapján jelen tanulmány empirikus módon vizsgálja a nemzetközi és hazai P2G-szegmenset, és a következő kérdésekre keresi a választ:

1. Milyen tudáshálózatokkal lehet jellemezni a fentiekben felvázolt együttműködéseket a szabályozók, az egyetemek és az ipari szereplők között a vizsgált szegmensben?

2. Hogyan járulhatnak hozzá az egyetemek és a szabályozók az ipari szereplők innovációs teljesítményének növeléséhez és ezzel a társadalmi hasznosság növekedéséhez is?

Az alábbiakban elöször a tanulmány szakirodalmi háttere olvasható, amely felvázolja a főbb elméleti kereteket. Ezután módszertana olvasható, majd ezt követi az eredmények és a következtetések ismertetése, amely utóbbi a kutatási kérdések megválaszolásán túl az empirikus eredmények alapján az elméleti keretrendszerre is visszacsatol.

10 Patrick R. Bixler et al.: An Observatory Framework for Metropolitan Change: Understanding Urban Social-Ecological-Technical Systems in Texas and Beyond. Sustainability, 11. (2019), 13. 3611; Jenny Palm - Magdalena Fallde: What Characterizes a System Builder? The Role of Local Energy Companies in Energy System Transformation. Sustainability, 8. (2016), 3. 256.

11 Liu Li - Chaoying Tang: How Does Inter-Organizational Cooperation Impact Organizations' Scientific Knowledge Generation? Evidence from the Biomass Energy Field. Sustainability, 13. (2021), 1. 191.

12 Bixler et al. (2019): i. m. 3611.

13 Sabrina Dressel et al.: Achieving Social and Ecological Outcomes in Collaborative Environmental Governance: Good Examples from Swedish Moose Management. Sustainability, 13. (2021), 4. 2329; Noella Edelmann - Ines Mergel: Co-Production of Digital Public Services in Austrian Public Administrations. Administrative Sciences, 11. (2021), 1. 22. 


\section{SZAKIRODALMI HÁTTÉR}

\subsection{Egyetemek és vállalatok közötti tudástranszfer}

A tanulmány legfontosabb elméleti alapvetése egyrészről, hogy Teece ${ }^{14}$ szerint bizonyos technológiai fejlesztések (innovációk) kiegészítő erőforrásokat igényelnek ahhoz, hogy ezeket a piacon is hasznosítsák, és ezeket a kiegészítő erőforrásokat (például tudást) külső szereplők (partnerek) is biztosíthatják. Ez átvezet szervezetközi innováció koncepciójához, amely Millar és társai ${ }^{15}$ alapján a szervezetek közötti innováció olyan komplex rendszere, amely kölcsönös tanulással, illetve különböző szakterületek és szervezetek között elosztott tudástermeléssel jellemezhető. Ez a gyakorlatban azt jelentheti például, hogy egy vállalat nem rendelkezik elegendő kapacitással és/vagy kompetenciával az alaptechnológiával kapcsolatos további kutatások elvégzéséhez, de az egyetemi kutatóközpontok új ismeretekkel szolgálhatnának a központi témában, a teljes technológiai folyamat hatékonyságának növelése érdekében.

Másodszor, a stratégiai kettős képesség irodalma szerint a versenyképes vállalatoknak hatékonyan kell müködniük a jelenlegi üzleti területeiken (kiaknázás), de egyszerre meg is kell újulniuk, és innovációkkal új üzleti területekre kell belépniük (felfedezés). ${ }^{16} \mathrm{~A}$ kiaknázás és a felfedezés között azonban ellentét feszül (például az erőforrások elosztását, a figyelem összpontosítását vagy a szervezeti mechanizmusokat tekintve), ami jelen van a tanulási tevékenységekben is. ${ }^{17}$ A szervezeti tanulás - amely stratégiai szempontból „az akciók javításának folyamata a jobb tudás és megértés révén"18 - felfedező és kiaknázó jellegének ellentéte gyakorlati szempontból például azt jelentheti, hogy vannak már jól ismert technológiák, amelyek esetében a kiaknázó tanulás már a hatékony ipari hasznosításra összpontosítana, de létezhetnek olyan új technológiák is, amelyek még számos ismeretlen technikai aspektussal rendelkeznek, így felfedező magatartást igényelnek.

$\mathrm{Az}$ innovációs hálózatok és a felfedező-kiaknázó tanulás megannyi vizsgálatra érdemes aspektusa közül jelen tanulmány az egyetemek és vállalatok közötti viszony kutatási résével foglalkozik. Míg számos tanulmány rámutatott az ipar-egyetem együttműködés előnyeire, Mascarenhas és társai szerint egyértelműen szükség lenne még a „partnerválasztás

14 David J. Teece: Profiting from Technological Innovation: Implications for Integration, Collaboration, Licensing and Public Policy. Research Policy, 15. (1986), 6. 285-305.

15 Jane Millar - Adrian Demaid - Paul Quintas: Trans-Organizational Innovation: A Framework for Research. Technology Analysis \& Strategic Management, 9. (1997), 4. 399-418.

16 Robert B. Duncan: The ambidextrous organization: Designing dual structures for innovation. In Ralph $\mathrm{H}$. Killman - Louis R. Pondy - Dennis Sleven (szerk.): The Management of Organization. New York, North Holland, 1976. 167-188.

17 James G. March: Exploration and exploitation in organizational learning. Organization Science, 2. (1991), 1. $71-87$.

18 Marlene C. Fiol - Marjorie A. Lyles: Organizational Learning. Academy of Management Review, 10. (1985), 4. 803 . 
folyamatát és ezen innovációs partnerségek müködését”"19 tanulmányozó kutatásokra. Ezen szempontok figyelembevétele a kutatáson belül leszűkíti fókuszt a tudásáramlásra az ipar és az egyetemek között, így lehetővé téve a P2G-szegmens mélyreható elemzését.

\subsection{Az együttmüködések jelentösége az energetikában}

Korábbi kutatások alapján az alacsony (vagy zéró) szén-dioxid-kibocsátású gazdaság kialakítása vagy a hidrogéngazdaságba való átmenet kihívásainak kezelése érdekében elkerülhetetlen a több szinten történő együttmüködés:

- Nemzetek feletti szinten globális megközelítést kell alkalmazni a globális probléma kezelésére, és nemzetközi konszenzusra van szükség, beleértve az alkalmazott technológiák szabványait és célkitüzéseit, valamint egy ütemtervet, amelyet az érintettek széles köre állapított meg, összhangban a nemzeti politikákkal. ${ }^{20}$

- Emellett a fenntartható energiarendszerek fejlesztése és megvalósítása érdekében az alacsonyabb szintű szereplők együttműködése is döntő fontosságú, amelyet szabályozói oldalról ösztönözni lehet. A megújuló energiaszektorban tevékenykedő vállalatoknak képesnek kell lenniük arra, hogy összegyűjtsék, azonosítsák, rendszerezzék és felhasználhassák a releváns információkat és azok forrásait, hogy versenyképesek legyenek. ${ }^{21}$

- Továbbá, több forrás is amellett érvel, hogy az egyetem-ipar tudásmegosztó hálózatban multidiszciplináris és gyakorlatorientált megközelítést kell alkalmazni, tudományos intézmények és helyi energiavállalatok bevonásával. ${ }^{22} \mathrm{Az}$ egyetemek és az ipar közötti együttműködés nemcsak lehetővé tenné a vállalatok számára, hogy gazdagítsák müszaki ismereteiket és megkönnyítsék a kutatási tevékenységeket, hanem erősítenék az egyetemek és az iparágak közötti bizalmat is. ${ }^{23}$ Végül, az egyetemek és az ipar közötti közös tudásteremtés az egyetemek számára kulcsfontosságú kutatási infrastruktúrát, gyakorlati jelentőségű naprakész tananyagot is biztosítana, és integrálná az egyetemi erőforrásokat az energiahatékony iparfejlesztési folyamatba. ${ }^{24}$

19 Carla Mascarenhas - João J. Ferreira - Carla Marques: University-Industry Cooperation: A Systematic Literature Review and Research Agenda. Science and Public Policy, 45. (2018), 5. 717.

20 Michel Noussan et al.: The Role of Green and Blue Hydrogen in the Energy Transition - A Technological and Geopolitical Perspective. Sustainability, 13. (2021), 1. 298.

21 Nicolae Istudor et al.: Theoretical Framework of Organizational Intelligence: A Managerial Approach to Promote Renewable Energy in Rural Economies. Energies, 9. (2016), 8. 639.

22 Xia Cao - Zeyu Xing - Keke Sun: Collaboration Network, Technology Network and Technological Development: A Patent Analysis in the Chinese Green Technological Field of Energy Saving. Foresight, 23. (2020), 1. 33-49; Xingwei Wang - Liang Guo: How to Promote University Students to Innovative Use Renewable Energy? An Inquiry-Based Learning Course Model. Sustainability, 13. (2021), 3. 1418.

3 Li-Tang (2021): i. m. 191.

24 Cao-Xing-Sun (2020): i. m. 
Ugyanakkor a kutatások arra is rámutattak, hogy e társadalmi előnyök (például fenntarthatóság, egyetemek és vállalatok versenyképesség-növekedése) realizálásához szükség lehet egy innovációs ökoszisztémára és egy ökoszisztéma-építőre, amely megteremti a kapcsolatot az akadémiai és ipari partnerek között. ${ }^{25} \mathrm{Ez}$ azért különösen fontos, mert a kapcsolódó $\mathrm{K}+\mathrm{F}$ - és technológiaimplementálási tevékenységekben részt vevő több és különböző szereplő fellépése gyakran nincs, vagy nincs megfelelően összehangolva. ${ }^{26}$ Egy ilyen innovációs ökoszisztémában a rendszerépítők (helyi szereplők, akik a rendszer fejlesztését és építését irányítják, például egy egyetem, egy állami szerv vagy egy vállalat) nemcsak az új technológiák bevezetésében játszanak központi szerepet, hanem releváns ismeretek összegyüjtésében, más szereplők összekapcsolásában és bevonásában, valamint az együttmüködés koordinálásában is. ${ }^{27}$

A fentieket összefoglaló elméleti keretrendszert az 1. ábra illusztrálja.

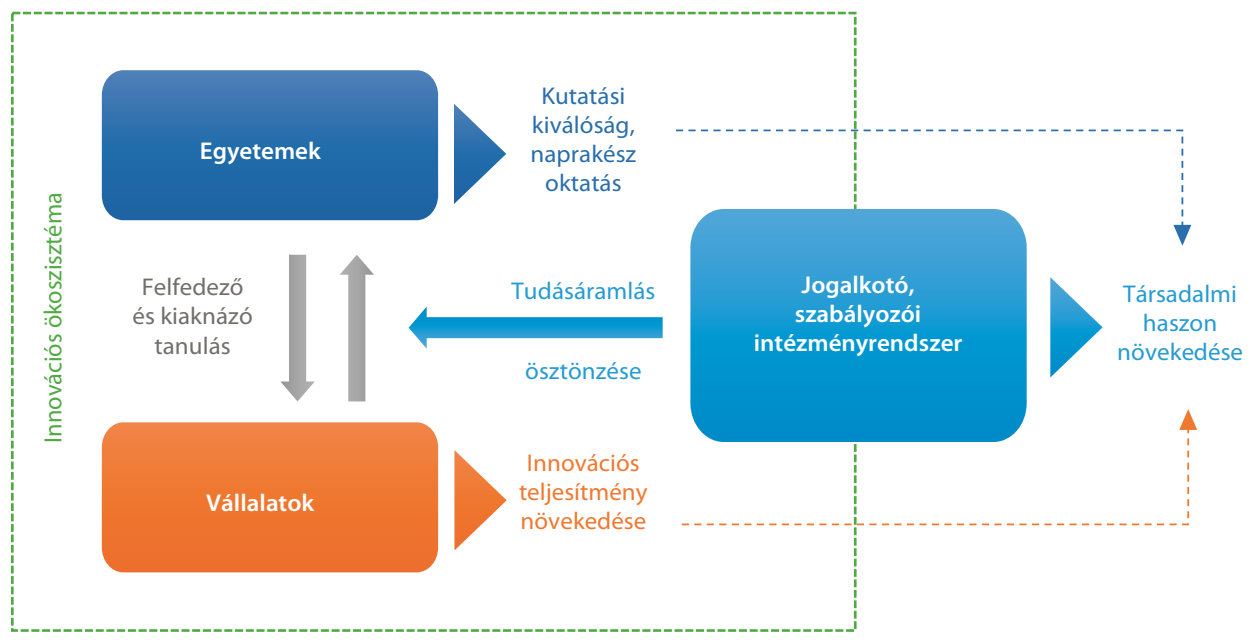

1. ábra • A tanulmány elméleti keretrendszere (Forrás: a szerzők szerkesztése)

25 Zoltán Csedő et al.: Hydrogen Economy Development Opportunities by Inter-Organizational Digital Knowledge Networks. Sustainability, 13. (2021), 16. 9194.

26 Bixler et al. (2019): i. m. 3611.

$27 \quad$ Palm-Fallde (2016): i. m. 256. 


\section{MÓDSZERTAN}

A kutatási kérdések megválaszolásához abduktív megközelítést alkalmaztunk, amely az empirikus adatok és az elmélet közötti iterációra helyezi a hangsúlyt. Ez azt jelenti, hogy

1. az empirikus adatok elemzése első lépésben mintázatok vagy jelenségek feltárását célozza;

2. majd ezeket összehasonlítják a korábbi kutatási eredményekkel és elméletekkel, a feltárt jelenségek magyarázása és esetleg új elméletek megalkotása céljából.

Ez az iteráció hangsúlyos több kutatási módszerben is, például a megalapozott elméletben (grounded theory, GT), ${ }^{28}$ a kiterjesztett esettanulmányban ${ }^{29}$ vagy a tágabb abduktív módszerelméletben (abductive theory of method, ATOM). ${ }^{30} \mathrm{E}$ kutatás mindezen módszertani gyökerek elemeit integrálta. Mivel „maga az ATOM grounded theory módszerként értelmezve kifejezetten befogadó mind a kvantitatív, mind a kvalitatív kutatási meglátások felé", ${ }^{31}$ a kutatás egyrészről kvantitatív szövegelemzéssel, másrészről az eredmények kvalitatív értelmezésével foglalkozott egy technológiafejlesztő cég szempontjából (empirikus eset mint kiindulópont). Jelen esetben ez a kiindulópont egy 2016-ban alapított, magyar P2G-technológiafejlesztő startup vállalat volt. A vállalat 2018-ban kifejlesztett egy innovatív P2G-prototípust, és nemrégiben kiterjesztette $\mathrm{K}+\mathrm{F}$-tevékenységeit a jövőbeli karbonsemleges, hidrogénalapú gazdaság még újabb területei felé is. A vállalat továbbá tagja a magyarországi Nemzeti Hidrogéntechnológiai Platformnak is. Elméleti keretrendszere alapján az adatgyüjtés és -elemzés a technológiai tudásáramlásra és a tudásfejlesztésre összpontosított 2016 és 2021 között, a vállalat szervezetközi, különösen az egyetemekkel és más iparági szereplőkkel történő kapcsolatain keresztül.

$\mathrm{Az}$ adatgyüjtés és -elemzés figyelembe vette az európai és a magyar kontextust is.

- Ami az európai kontextust illeti, a releváns P2G-projektleírásokat a vállalat K+Ftechnológiai platformjából gyüjtöttük ki. Ezek a projektleírások közvetlen benchmarkingcélokat szolgálnak a vállalat számára a jövőbeli projekttervezéshez, és az alkalmazottak piackutatási tevékenységére vagy külső szakemberek és más iparági szereplők javaslataira épülnek. A kiválasztási kritérium alapján csak európai projektek voltak relevánsak. Ezenkívül a szerzők hosszú publikációs listát állítottak össze a potenciálisan a tárgyhoz tartozó cikkekröl, amelyek relevánsak lehetnek a P2G-üzemek fejlesztése szempontjából $(\mathrm{N}>250)$. A cél a lehetőségek széles skálájának biztosítása volt, annak érdekében, hogy elkerüljük a releváns témák

28 Barney G. Glaser - Anselm L. Strauss: The Discovery of Grounded theory: Strategies for Qualitative Research. Chicago, Aldine, 1967.

29 Michael Burawoy: The Extended Case Method. Sociological Theory, 16. (1998), 1. 4-33.

30 Brian D. Haig: Grounded Theory Method. In Method Matters in Psychology. Studies in Applied Philosophy, Epistemology and Rational Ethics. Springer, Cham, 2018. 89-107.

$31 \quad$ Haig (2018): i. m. 106. 
nemkívánatos leszűkítését, ugyanis ez korlátozhatta volna a kutatás abduktív értelemben vett megbízhatóságát. A lista témái:

a) power-to-hydrogen ( $\mathrm{P} 2 \mathrm{H}$ : víz elektrolízise megújuló villamos energiával);

b) power-to-methane (P2M: hidrogén és szén-dioxid átalakítása szintetikus, megújuló vagy karbonsemleges metánná);

c) power-to-liquid (P2L: folyékony, karbonsemleges szén-hidrogének, például dízel előállítása);

d) power-to-X (P2X, az előzőek átfogó kategóriája);

e) Carbon Capture (CC, amely révén szén-dioxid biztosítható a P2M-hez és a P2L-hez ipari létesítmények füstgázából).

Végül 63 db, elsősorban a metanizációra fókuszáló P2G-publikációt választottunk ki, amelyek az adatokban az akadémiai tudásforrásokat képviselték. Ezen kívül a projektleírások és a publikációk elemzését összehasonlítottuk a karbonsemlegességre vonatkozó EU-s stratégiákkal is. ${ }^{32}$

- Ami a magyar kontextust illeti, az adatgyüjtés több mint 30 félig strukturált interjú készítését (a vállalat alkalmazottjaival, érintettekkel és partnerekkel, beleértve az egyetemek kutatóit és az iparvállalati partnerek vezetőit), valamint a vállalat $\mathrm{K}+\mathrm{F}$ Technológiai Platform további tartalmának elemzését foglalta magában. Ez a vállalat nyitott innovációs folyamatainak eredményeként létrejött 336 tudáselemet tartalmazott (dokumentált technológiai know-how-k, innovációval kapcsolatos kérdések és ötletek, valamint e-learning-anyagok). Az interjúk egyik célja e vállalati tudáselemek kategorizálása volt forrás, cél és szektorális kapcsolódás (például energiagazdaság-tan) szerint.

Az eredmények hibrid, kvantitatív-kvalitatív adatelemzésre épülnek, amelyben a kvantitatív rész a projektleírások, publikációk és EU-s dokumentumok szövegelemzését jelentette a JMP-szoftver segítségével. E kvantitatív elemzés támogató jellege alapján reprezentatív megközelítést (és nem instrumentális megközelítést) alkalmaztunk a források jelentéseinek azonosítására. A kvantitatív elemzés - az interjúkkal párhuzamosan - főként tematikus és hálózati szövegelemzést tartalmazott, ${ }^{33}$ de a trendek azonosítása is releváns volt. Az elemzett szövegek angol nyelvüek voltak, az eredmények bemutatásánál azonban az illusztratív kulcsszavakat magyarul tüntetjük fel.

32 European Commission: A Clean Planet for all. A European strategic long-term vision for a prosperous, modern, competitive and climate neutral economy COM(2018) 773 final (2018. november 28.); European Commission: The European Green Deal COM(2019) 640 final (2019. december 11.); COM(2018) 773 final, Annex; European Parliament: European Parliament resolution of 15 January 2020 on the European Green Deal [2019/2956(RSP)]. 2020.

33 Carl W. Roberts: A Conceptual Framework for Quantitative Text Analysis. Quality and Quantity, 34. (2000), 3. 259-274. 


\section{EREDMÉNYEK}

A következőkben az európai és a hazai kontextus elemzésének bemutatására, illetve a tanulságok szabályozói szempontból történő értelmezésére kerül sor, elsősorban a társadalmi hasznosság növelését célozva.

\subsection{Tanulságok az európai kontextus elemzése alapján}

Az európai kontextus vizsgálata két fő részből áll. Egyrészről szükséges volt feltárni, hogy milyen egyetem-ipar együttmüködések azonosíthatók a vizsgált szegmensben, például a projektek célját és résztvevőit tekintve. Másrészről kiemelt figyelmet érdemelt annak kutatása is, hogy az ipari projektek és tudományos kutatások tartalma hogyan kapcsolódik a tágabb, szabályozói oldalról megfogalmazott célrendszerhez.

\subsubsection{Egyetem-ipar együttmüködések a vizsgált szegmensben}

A szerzők adatgyüjtése alapján a szervezetek közötti K+F-együttműködések, amelyekben az ipar képviselői és az egyetemek is részt vesznek, rendkívül relevánsak a P2Gszegmensben, ugyanis ezeket a technológiákat gyakran fejlesztik és valósítják meg olyan demonstrációs vagy kereskedelmi méretű projektek keretében, amelyek szervezetközi együttműködésekre épülnek. A projektek keretében a szereplők kombinálják a komplementer képességeiket az innovatív P2G-technológia potenciáljának a kiaknázása érdekében (például alaptechnológia egy innovatív startuptól, átfogó ipari ismeretek és erőforrások egy energetikai nagyvállalattól, tudományos ismeretek és kutatási kapacitás egy egyetemtől, vagy pénzügyi erőforrások egy stratégiai befektetőtőll). ${ }^{34} \mathrm{~A}$ korábbi szakirodalom, a hivatalos bejelentések és a projektek zárójelentései alapján az 1. táblázat azokat az európai P2G-projekteket mutatja be, amelyekben a vállalatok olyan partnerekkel dolgoztak együtt, akik képesek voltak az ipari kutatás és fejlesztés kiegészítésére a tudományos ismeretek felhasználásával.

34 Csedő-Zavarkó (2020): i. m. 
1. táblázat • P2G-projektek, ipari és akadémiai szereplók együttmüködésével (Forrás: a szerzök szerkesztése Bailera et al., 2019; Ghaib - Ben-Fares, 2018; Deutsche EnergieAgentur, 2018; European Commission - CORDIS, 2018; Karlsruhe Institute of Technology, 2018; IEA Bioenergy, 2018; Electrochaea, 2017; RAG Austria, 2017, 2018 alapján)

\begin{tabular}{|c|c|c|c|c|}
\hline Projekt & Helyszín & Egyedi jellemző & Ipari tudás & Tudományos tudás \\
\hline $\begin{array}{l}\text { Audi e-gas } \\
\text { üzem }\end{array}$ & $\begin{array}{l}\text { Werlte, } \\
\text { Németország }\end{array}$ & $\begin{array}{l}\text { Legnagyobb } \\
\text { kémiai } \\
\text { metanizációs } \\
\text { üzem } \\
\end{array}$ & $\begin{array}{l}\text { ETOGAS, EWE Biogas, } \\
\text { Audi }\end{array}$ & ZSW, Fraunhofer IWES \\
\hline HELMETH & $\begin{array}{l}\text { Karlsruhe, } \\
\text { Németország }\end{array}$ & $\begin{array}{l}\text { Innovatív } \\
\text { elektrolízis- } \\
\text { technológia }\end{array}$ & $\begin{array}{l}\text { Sunfire, German } \\
\text { Technical and } \\
\text { Scientific Association } \\
\text { for Gas and Water }\end{array}$ & $\begin{array}{l}\text { Polytechnic University of } \\
\text { Turin, European Research } \\
\text { Institute of Catalysis, } \\
\text { National Technical } \\
\text { University of Athens }\end{array}$ \\
\hline BioPower2Gas & $\begin{array}{l}\text { Allendorf, } \\
\text { Németország }\end{array}$ & $\begin{array}{l}\text { Első kereskedelmi } \\
\text { üzem } \\
\text { biometanizációval }\end{array}$ & $\begin{array}{l}\text { Microbenergy, } \\
\text { Viessmann Group } \\
\text { EAM EnergiePlus, } \\
\text { EnergieNetz Mitte }\end{array}$ & $\begin{array}{l}\text { iDe (Institue of } \\
\text { Decentralized Energy } \\
\text { Technologies), DBFZ } \\
\text { (German Biomass Research } \\
\text { Centre) }\end{array}$ \\
\hline BioCat & $\begin{array}{l}\text { Avedøre, } \\
\text { Dánia }\end{array}$ & $\begin{array}{l}\text { Legnagyobb } \\
\text { biológiai } \\
\text { metanizációs } \\
\text { üzem }\end{array}$ & $\begin{array}{l}\text { Electrochaea, } \\
\text { Energinet, } \\
\text { Hydrogenics, NEAS } \\
\text { Energy, HMN } \\
\text { Gashandel A/S, Biofos } \\
\text { A/S, Audi, Insero }\end{array}$ & University of Chicago \\
\hline $\begin{array}{l}\text { Underground } \\
\text { Sun Storage }\end{array}$ & $\begin{array}{l}\text { Pilsbach, } \\
\text { Ausztria }\end{array}$ & $\begin{array}{l}\text { Föld alatti } \\
\text { metanizációs } \\
\text { folyamat }\end{array}$ & RAG, Verbund, Axiom & $\begin{array}{l}\text { University of Leoben, } \\
\text { University of Natural } \\
\text { Resources and Applied Life } \\
\text { Sciences Vienna, } \\
\text { Energy Institute at the } \\
\text { Johannes Kepler University }\end{array}$ \\
\hline $\begin{array}{l}\text { STORE\&GO } \\
\text { - Olaszország }\end{array}$ & $\begin{array}{l}\text { Troia, } \\
\text { Olaszország }\end{array}$ & $\begin{array}{l}\text { Szén-dioxid- } \\
\text { megragadás } \\
\text { a levegőből } \\
\text { a metanizációhoz }\end{array}$ & \begin{tabular}{|l|} 
Climeworks AG, \\
Studio Tecnico BFP, \\
Engineering Ingegneria \\
Informatica SPA, Iren \\
SPA, ATMOSTAT, \\
Hysytech S.R.L., \\
Comune di Troia
\end{tabular} & $\begin{array}{l}\text { Politecnico di Torino, CEA } \\
\text { French Alternative Energies } \\
\text { and Atomic Energy } \\
\text { Commission }\end{array}$ \\
\hline
\end{tabular}

\subsubsection{Szabályozói, egyetemi és vállalati preferenciák és tudásbázisok}

Az európai P2G-projektleírások, a releváns publikációk absztraktjainak és az EU-s stratégiai dokumentumok kvantitatív szövegelemzése, továbbá az eredmények interjúk általi értelmezése alapján azonosíthatóvá váltak a szabályozói, az egyetemi és a vállalati prioritások.

A felsorolt projektek rövid összefoglalói (21 leírás, átlagosan körülbelül 1-3 oldal; összesen 2501 kifejezés) alapján a leggyakoribb kifejezés a „hidrogén”. Hasonlóan meghatározó 
szavak a „szén-dioxid” és a „metán”. Ez az eredmény bár nem különösebben meglepő, a hidrogén relatív dominanciája a többi kulcsfogalommal (például metán, tárolás, biogáz, földgáz) szemben feltűnő. Ami a hidrogéngazdaság felé irányuló tendenciát és előrehaladást illeti, ${ }^{35}$ a hidrogénorientáció indokolt lehet, de például kérdésként merülhet fel, hogy mi lehet a metanizációs P2G-technológiák (biometán vagy SNG-előállítás) szerepe a hidrogéngazdaságban? Ez további elemzést igényel a tudományos publikációk és az EU-s politikák alapján.

A kiválasztott publikációk esetében a szófelhőn (2. ábra) némileg más minta látható, mint a projektleírásoknál. Például, bár a hidrogén és a szén-dioxid egyaránt fontosak, a szén-dioxid gyakrabban jelenik meg a kutatási dokumentumokban, míg a hidrogénhasznosítás gyakrabban jelenik meg a projektleírásokban. Szintén különbség, hogy a tudományos kutatás inkább a „rendszer”, a „folyamat” vagy a „reaktor” operatív kérdéseivel foglalkozik, míg a projektek leírásai a „technológia felhasználásáról” és a metán „termeléséről” írnak az „energiatároláshoz”.

A 2. ábra a vizsgált publikációk, a projektleírások és az EU-s dokumentumok leggyakoribb kifejezéseinek összehasonlítását mutatja. Az említett tendenciáknak megfelelően, kvantitatív szempontból a szén-dioxid $(\mathrm{N}=116)$, a hidrogén $(101)$, a metán $(92)$, a rendszer (79) és a power-to-gas (77) kifejezések dominánsak a tudományos publikációk esetében. A projektleírások is erre a három kifejezésre összpontosítottak, de más kulcsszavakkal: hidrogén (104), metán (90), szén-dioxid (80), felhasználás (80), energia (77), gáz (77). Ezzel szemben az EU-s dokumentumokat tekintve a leggyakoribb kifejezések az energia (157), az üvegházhatású gázok kibocsátása (88), a gazdaság (87), a csökkentés (69), a szektorok (68) és a fenntartható (68). Ennek megfelelően a fö cél az „üvegházhatást okozó gázok kibocsátásának” (ÜHG) „csökkentése” a „fenntartható” „átmenet” révén, több „megújuló energiával”. Ugyanakkor fontos a „gazdaság” és a „versenyképesség” növelése „globális” „környezetben” az „éghajlatváltozás” elleni küzdelem során is. Például az Európai Bizottság Tiszta bolygót mindenkinek elnevezésű dokumentuma már az Európai hosszú távú stratégiai jövőkép egy virágzó, modern, versenyképes és klímasemleges gazdaságról alcímben is hivatkozik a versenyképességre. ${ }^{36}$ Ezt támasztja alá az a megállapítás is, hogy az „Európai zöld megállapodás célja, hogy az EU-t igazságos és virágzó társadalommá alakítsa, modern, erőforrás-hatékony és versenyképes gazdasággal”. ${ }^{77}$

John O. Abe et al.: Hydrogen Energy, Economy and Storage: Review and Recommendation. International Journal of Hydrogen Energy, 44. (2019), 29. 15072-15086.

36 European Commission (2018): i. m.

37 European Commission (2019): i. m. 2. 


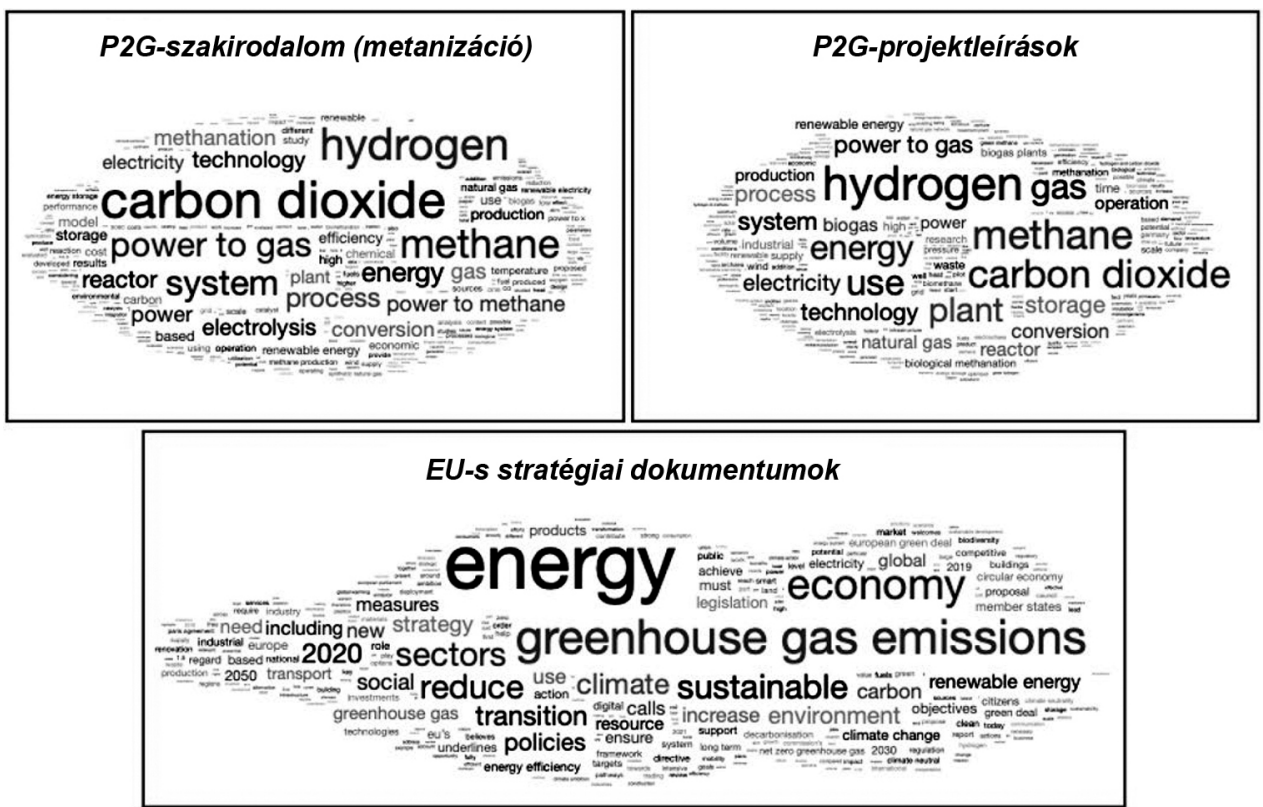

2. ábra • A nemzetközi (angol nyelvü) P2G-projektleírások, a P2G tudományos publikációk és a releváns EU-s stratégiai dokumentumok szófelhőinek összehasonlitása (Forrás: a szerzők szerkesztése)

Ezek az eredmények arra utalnak, hogy a tudományos kutatásoknak, az ipari projektfejlesztéseknek és az EU-s stratégiáknak vannak közös pontjaik, például az ÜHG-csökkentés indukálja a szén-dioxid-leválasztási és -hasznosítási (CCU-) megoldásokra és azok P2G üzemekben való ipari alkalmazására fókuszáló tudományos kutatásokat. Ugyanakkor, a prioritások és a fó témák nem tökéletesen illeszkednek, és a téma magas K+F+I-igénye miatt szükség lehet a tudás áramoltatására a szabályozói, az egyetemi és az ipari szereplők között.

\subsection{Tanulságok a hazai kontextus elemzése alapján}

Az európai kontextus elemzése alapján lehetséges volt a tudásáramlás iránti potenciális igény azonosítása, azonban e tudásáramlás konkrét fókuszterületei már nem voltak meghatározhatók ilyen magas elemzési szinten. Következésképp sor került a hazai P2G innovációs ökoszisztéma elemzésére is. 


\subsubsection{Tudásszükségletek megnyilvánulása}

A hazai kontextusban az eredmények arra engednek következtetni, hogy a tudományos és ipari tudásforrások a know-how-áramlás folyamán a P2G-technológia fejlesztésének különböző aspektusaira összpontosítanak, és olyan kiegészítő tudások azonosíthatók, amelyek kombinálása a technológiai innovációkból származó előnyök realizálása érdekében szükséges. ${ }^{38} \mathrm{Az}$ adatbázisban legalább tízszer előforduló kifejezések $(\mathrm{N}=649)$ és az érdekelt felekkel készített interjúk alapján a 3. ábra a különböző kifejezések megjelenési arányát mutatja be (minden pont egy kifejezést jelent) a tudáselemekben meghatározott attribútumkombinációk szerint (például ipari forrás, valamint biológiai vagy kémiai technológiai kapcsolat). Az ábra jelentősége, hogy megmutatja az akadémiai szféra és az ipar közötti jelentős komplementaritást a P2G technológiafejlesztés kulcsfontosságú területein. Az akadémiai és ipari partnerek többnyire eltérö erösségekkel rendelkeznek a szektorkapcsolatok tekintetében:

- Az ipari forrásokból származó tudáselemekben gyakran megjelenő kifejezések lazán kapcsolódnak a biotechnológiához és vegyészethez (az ábrán az I1 cella) vagy az energiagazdaság-tanhoz (I3), míg az akadémiai tudáselemek gyakran inkább ezekhez a kifejezésekhez kapcsolódnak (A1 és A3).

- A közgazdaságtanhoz, a gazdálkodáshoz és a menedzsmenthez kapcsolódó knowhow-bázis többnyire ipari tudásforrásokból származik (I2), míg az akadémiai források ezekben a témákban alig jelennek meg a P2G-szegmensben (A2). Ez az eredmény azzal magyarázható, hogy számos P2G-technológia korai fejlődési stádiumban van, tehát még nem eléggé kiforrottak ahhoz, hogy üzleti jellegű problémákat generáljanak a kutatók számára.

- Ami a mérnöki területeket illeti, az ipari források domináltak az adatokon belül, de itt a különbség az akadémiai kapcsolódáshoz képest gyengébb. Az interjúk alapján ezt azzal kell árnyalni, hogy a startup a prototípus szintjén kezdte meg fejlesztési tevékenységét, a biotechnológiára összpontosítva, míg a mérnöki tevékenység a technológia felskálázásakor válik egyre fontosabbá.

Ezek az eredmények arra engednek következtetni, hogy az egyetemek és kutatóközpontok jelenleg leginkább a biotechnológiával vagy vegyészettel és az energiagazdaság-tannal kapcsolatos területekhez járulnak hozzá, míg az ipari partnerek üzleti és menedzsment, valamint mérnöki szempontból befolyásolják a know-how-bázis fejlődését. Továbbá az eredmények arra is utalnak, hogy nem elegendő csupán megteremteni a kapcsolatot egy-egy egyetem és vállalat között, hanem a különböző tudásforrások és tudásterületek összekapcsolására van szükség a P2G innovációs ökoszisztémában, ami felértékeli a szabályozói ösztönzés szerepét minél több - releváns tudást birtokló - szereplö bevonásában.

Edelmann-Mergel (2021): i. m. 22. 


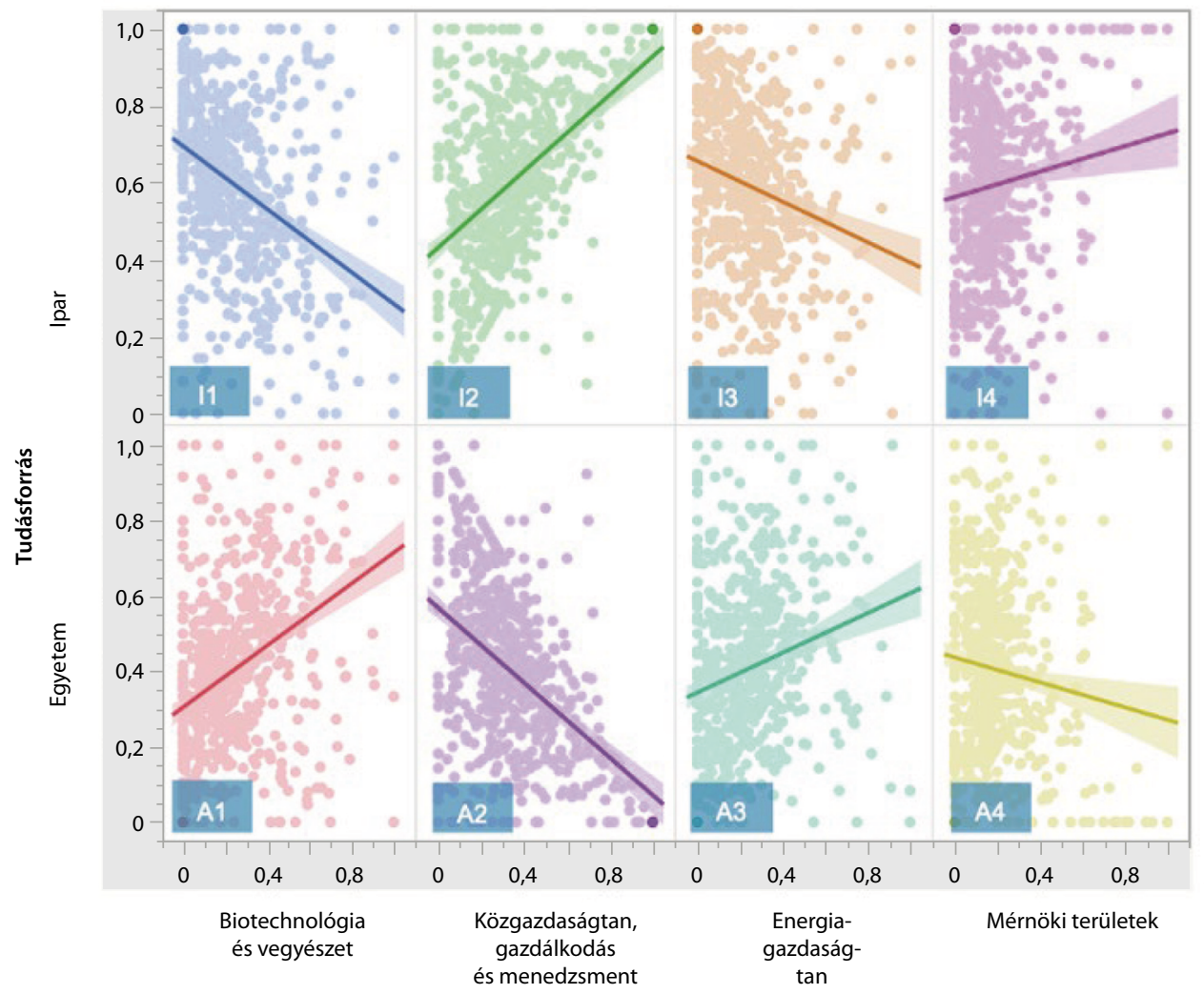

Szektorális kapcsolat

3. ábra • A leggyakoribb kifejezések megjelenési aránya a forrásuk és a szektorális kapcsolatuk szerint (Forrás: a szerzők szerkesztése)

\subsubsection{A felfedezö és kiaknázó tanulás értelmezése}

Az elméleti keretrendszer egyik fontos pillére volt a kiaknázó és a felfedező tanulás közötti ellentét. Ebből a szempontból nyilvánvalónak tűnne, hogy az egyetemek és kutatóközpontok a felfedezéshez járulnak hozzá a kutatási kapacitásaik alapján, míg az energetikai vállalatok a kiaknázó tanulást segítik elő meglévő üzleti és infrastrukturális kompetenciáik alapján. Az empirikus eredmények alapján azonban ez csak részben igaz, ráadásul az egyetemek vagy az ipar hozzájárulása a kiaknázáshoz vagy a felfedezéshez a kettős képesség értelmezésének szintjétől (szektor vagy vállalati szint) is függ.

A vizsgált szegmensben az egyetemek föként olyan új megoldások kifejlesztésére összpontosítottak, amelyek javíthatják a $\mathrm{P} 2 \mathrm{H}$ - és $\mathrm{P} 2 \mathrm{M}$-folyamatlánc általános hatékonyságát (például az alacsony hőmérsékletű hulladékhő hasznosítása). Annak ellenére, hogy 
ez úításokat igényel, ezek a technológiák a fókuszban lévő vállalat meglévő üzletágát képviselik, azaz ezek a fejlesztések a kiaknázó tevékenységeket támogatják vállalati szinten. Ugyanakkor, ez a szektor szempontjából még felfedezést jelent, hiszen a P2H és a P2M még nem terjedt el széles körben sem Magyarországon, sem világszerte. Emellett az ipari szereplők kiaknázó szerepe is kétértelmű lehet. Annak ellenére, hogy széles körű ismeretekkel szolgálhatnának a jelenlegi infrastruktúráról és lehetőségekről, az ipari partnerek a vizsgált szegmensben a felfedezést előbbre mozdították (mozdítják) azzal, hogy a technológiafejlesztők és az egyetemek figyelmét a szén-dioxid-leválasztással kapcsolatos technológiai fejlesztésekre, innovációkra irányítják. Az egyetemek tehát képesek támogatni az energetikai vállalatok kiaknázó tevékenységét, az energetikai nagyvállalatok pedig az egyetemek felfedező tevékenységét egy „innovációs ökoszisztémában”, egy dinamikus és alkalmazkodó rendszerben, amelyben a szereplők különböző képességekkel, szerepekkel és motivációkkal rendelkeznek, de együttmüködnek az innovációs folyamat sikere érdekében. ${ }^{39}$

Szabályozói szempontból azt érdemes figyelembe venni, hogy az egyetemek nem csak az alapkutatásban képesek hozzáadott értéket teremteni a vállalatok számára, de a vizsgált szegmensben a központi technológiai innováció határterületein már alkalmazott ipari kutatással segíthetik az új megoldások felskálázását. A 2. táblázat összefoglalja a P2G innovációs ökoszisztéma szempontjából az adatgyüjtés, az adatelemzés és korábbi szakirodalmi eredmények szintézisén alapuló megállapításokat. Mivel a kiaknázás és felfedezés témái sohasem statikusak, a táblázat inkább csak „pillanatfelvételt” nyújt, de azt megvilágítja, hogy a szereplőknek egymást kiegészítő tudásuk miatt együttmüködésben kell megvalósítaniuk a kiaknázást és a felfedezést. Amint arra a táblázat is rámutat, a felfedezéskiaknázás témakör és a tágabb egyetemi-ipari kapcsolatok kutatása során már elötérbe kerültek a központi vállalat jelenlegi technológiájához eddig lazábban kapcsolódó technológiai területek is (power-to-hydrogen, power-to-liquid, carbon capture).

2. táblázat • Kiaknázó és felfedezö tanulás a vizsgált szegmens innovációs ökoszisztémájában (Forrás: a szerzök szerkesztése)

\begin{tabular}{|c|c|c|c|}
\hline & $\begin{array}{l}\text { Kiaknázó tanulási } \\
\text { területek } \\
\text { (példák az empíria } \\
\text { alapján) } \\
\end{array}$ & $\begin{array}{l}\text { Felfedező tanulási } \\
\text { területek } \\
\text { (példák az empíria } \\
\text { alapján) } \\
\end{array}$ & $\begin{array}{l}\text { Domináns hozzájárulás } \\
\text { az energiaszektor versenyképességének } \\
\text { javításához } \\
\text { (példák az empíria alapján) }\end{array}$ \\
\hline $\begin{array}{l}\text { Akadémiai } \\
\text { partnerek }\end{array}$ & $\begin{array}{l}\text { A központi P2G } \\
\text { technológiai know-how } \\
\text { kiaknázásának } \\
\text { támogatása } \\
\text { inkrementális } \\
\text { fejlesztésekkel } \\
\text { a magasabb hatékonyság } \\
\text { érdekében }\end{array}$ & $\begin{array}{l}\text { Hatékony szén-dioxid- } \\
\text { leválasztási megoldások } \\
\text { és más kémiai } \\
\text { konverziós eljárások (pl. } \\
\text { P2L) fejlesztése }\end{array}$ & $\begin{array}{l}\text { Kiaknázás: reakciók modellezése, } \\
\text { hatékonyságvizsgálatok, } \\
\text { szcenárióelemzések a technológiai } \\
\text { integrációkról és a P2G potenciáljáról } \\
\text { Felfedezés: innovatív üzleti modellek } \\
\text { és technológiai megoldások kidolgozása } \\
\text { szén-dioxid-leválasztással és power-to- } \\
\text { liquid folyamatokkal }\end{array}$ \\
\hline
\end{tabular}

39 James Boyer: Toward an Evolutionary and Sustainability Perspective of the Innovation Ecosystem: Revisiting the Panarchy Model. Sustainability, 12. (2020), 8. 3232. 


\begin{tabular}{|l|l|l|l|}
\hline & $\begin{array}{l}\text { Kiaknázó tanulási } \\
\text { területek } \\
\text { (példák az empíria } \\
\text { alapján) }\end{array}$ & $\begin{array}{l}\text { Felfedező tanulási } \\
\text { területek } \\
\text { (példák az empíria } \\
\text { alapján) }\end{array}$ & $\begin{array}{l}\text { Domináns hozzájárulás } \\
\text { az energiaszektor versenyképességének } \\
\text { javításához } \\
\text { (példák az empíria alapján) }\end{array}$ \\
\hline $\begin{array}{l}\text { Ipari } \\
\text { partnerek }\end{array}$ & $\begin{array}{l}\text { A központi P2G } \\
\text { technológiai know-how } \\
\text { hasznositása } \\
\text { kereskedelmi léptékben }\end{array}$ & $\begin{array}{l}\text { A szén-dioxid- } \\
\text { leválasztási és az egyéb } \\
\text { kémiai konverziós } \\
\text { (pl. P2L) fejlesztésének } \\
\text { támogatása } \\
\text { infrastrukturális } \\
\text { tudással } \\
\text { és finanszírozással }\end{array}$ & $\begin{array}{l}\text { Kiaknázás: versenyelöny } \\
\text { szerzése az EU-piacokon } \\
\text { a költségek csökkentésével, új } \\
\text { megoldások bevezetésével, a teljes } \\
\text { rendszerhatékonyság P2G-technológiák } \\
\text { általi fejlesztésével } \\
\text { Felfedezés: szén-dioxid-leválasztási, } \\
\text { dekarbonizációs projektek megvalósítása } \\
\text { és karbonsemleges üzemanyagok } \\
\text { gyártása más szektoroknak is } \\
\text { (pl. közlekedés) } \\
\text { power-to-liquid folyamatokkal }\end{array}$ \\
\hline $\begin{array}{l}\text { Innovációs } \\
\text { ökoszisz- } \\
\text { téma }\end{array}$ & $-\quad$ & $\begin{array}{l}\text { A rendszerintegráció és múködtetés új módjainak felfedezése, } \\
\text { hasznosítva az új technológiákat és hozzájárulva a fenntarthatósági } \\
\text { törekvésekhez }\end{array}$ \\
\hline
\end{tabular}

\subsection{Szabályozói prioritások és a potenciális társadalmi hasznosság}

Az eddig bemutatott eredmények alapján a vállalati innovációs teljesítmény érdekében szükség van az egyetemek bevonására, és következésképp az egyetemek és a vállalati szektor összekapcsolására egy-egy innovációs ökoszisztémában. A P2G innovációs ökoszisztémák támogatása azonban attól is függ, mennyiben tudnak hozzájárulni az európai és hazai társadalmi-gazdasági előrehaladáshoz.

Ezen a területen az eredmények egyértelműen napjaink két fő trendjének (célkitűzésének), a zöld hidrogéntermelés és -hasznosítás, illetve a dekarbonizáció P2G általi összekapcsolását helyezik a középpontba. A hidrogént határozottan „kiemelt területnek” tekintik ${ }^{40}$ az EU-ban. Minél több hidrogént termelnek a hidrogéngazdaságban, annál nagyobb szükség lesz annak hatékony tárolására vagy hasznosítására, különösen azért, mert a hidrogén földgázhálózatba való betáplálását biztonsági szempontból korlátozzák. ${ }^{41}$ A metanizációs P2G-technológia így olyan módszerként működhet, amely a hidrogén szintetikus földgáz (SNG) formájában történő tárolására és/vagy hasznosítására alkalmas nagy mennyiségben és hosszú távon, vagy középső lépés lehet más egyéb formában történő alkalmazáshoz (például LNG). Ez összhangban van az uniós stratégiákkal is, például: „A fenntartható megújuló fütés továbbra is fontos szerepet játszik, és a gáz, beleértve a cseppfolyósított földgázt, hidrogénnel keverve, vagy a megújuló villamos energiából és biogáz keverékekből előállított e-metán, mind kulcsfontosságú szerepet játszhat a meglévő épületek fütésében, valamint számos ipari alkalmazásban”.42

\footnotetext{
$40 \quad$ European Commission (2019): i. m. 8.

${ }^{41}$ Zine labidine Messaoudani et al.: Hazards, Safety and Knowledge Gaps on Hydrogen Transmission via Natural Gas Grid: A Critical Review. International Journal of Hydrogen Energy, 41. (2016), 39. 17511-17525.

42 European Commission (2018): i. m. 8.
} 
A dekarbonizáció szintén fó célkitűzés az EU-n belül: „az energiarendszer további dekarbonizálása kritikus fontosságú az éghajlatváltozással kapcsolatos célok eléréséhez 2030-ban és 2050-ben." ${ }^{33}$ Ezen a területen kihívást jelent a P2G esetében, hogy a metanizációhoz hatékonyan használható $\mathrm{CO}_{2}$-forrásokra van szükség, amelyek biogázvagy bioetanol-üzemeknél ugyan elérhetők, de ezek néha nincsenek közel a földgázhálózathoz (ez az energiatárolás miatt releváns), és nincs elegendő $\mathrm{CO}_{2}$ sem a nagyobb (több MW elektrolizátor kapacitású) üzemek működtetéséhez. ${ }^{44}$ Ezenkívül a füstgázból történő szén-dioxid-leválasztási megoldásokat kereskedelmi méretekben még gyakran drágának és kiforratlannak tartják, ${ }^{45}$ annak ellenére, hogy számos kutatást végeztek és végeznek jelenleg is a különböző helyzetekben hatékonynak tűnő megoldásokról. ${ }^{46}$ Ígéretes irány lehet azonban a szén-dioxid-leválasztási technológiák és a P2G közös kutatása és fejlesztése, Bailera és társai ${ }^{47}$ kutatásaihoz hasonlóan. Amellett, hogy az erőforrások, technológiák együttes specializációja általában versenyelőnyhöz vezethet dinamikus versenykörnyezetben, ${ }^{48}$ a környezeti feltételek és a kutatási eredmények is ezen irány követését indokolják. Például a P2G-rendszerek bevezetésével csökkenthetők a károsanyag-kibocsátások, így környezeti hatásuk pozitív, és a pozitívumok többsége is az éghajlatváltozás területén mutatható ki. ${ }^{49}$ Továbbá, a szintetikus metán kiemelkedő üvegházhatásúgázmegtakarítást kínál, ha biogén szén-dioxid-forrásokat használnak a metanizációs folyamatban, vagy a hidrogén elektrolízissel és megújuló energiával történő előállítása során, ${ }^{50}$ de a karbonsemlegesség elérhető lehet füstgázra vonatkozó szén-dioxid-leválasztási megoldásokkal is.

A hazai környezetben szintén hasonló hozzájárulásokra lehet számítani. A tervek szerint 2030-ra a hazai villamosenergia-termelés 90\%-a $\mathrm{CO}_{2}$-mentes lesz. A P2G telepítése az ÜHG-intenzív ipari tevékenységek mellé és az ipari szén-dioxid használata is ígéretes a metanizációs lépésen belül, mivel fontos cél az ÜHG-intenzív ipari tevékenységek versenyképességének növelése ezen a területen tett előrelépésekkel. A biogáz előállítása és tisztítása szintén hozzájárulhat a dekarbonizációs célok eléréséhez, és különösen igaz ez olyan P2G-üzemeknél, amelyekben a szén-dioxid metánná alakítható. Továbbá, mivel prioritás

43 European Commission (2018): i. m. 8.

44 Csedő - Sinóros-Szabó - Zavarkó (2020): i. m. 4973.

45 Gábor Pörzse - Zoltán Csedő - Máté Zavarkó: Disruption Potential Assessment of the Power-to-Methane Technology. Energies, 14. (2021), 8. 2297.

46 Carnegie Mellon University: IECM Technical Documentation: Amine-based Post-Combustion CO2 Capture. Pittsburgh, (2018. június); Rohan Stanger et al.: Oxyfuel Combustion for CO2 Capture in Power Plants. International Journal of Greenhouse Gas Control, 40. (2015), 55-125.

47 Manuel Bailera et al.: Integration of Amine Scrubbing and Power to Gas. In Energy Storage. Springer, Cham, 2020. 109-135; Manuel Bailera et al.: Power to Gas-Electrochemical Industry Hybrid Systems: A Case Study. Applied Energy, 202. (2017), 435-446.

48 David J. Teece: Explicating Dynamic Capabilities: The Nature and Microfoundations of (Sustainable) Enterprise Performance. Strategic Management Journal, 28. (2007), 13. 1319-1350.

49 P. F. Van Den Oosterkamp: Full CBA Analysis of Power-to-Gas in the Context of Various Reference Scenarios. Bonn, STORE\&GO Project, 2018.

50 Haji Blanco: Report on Full CBA Based on the Relevant Environmental Impact Data. Bonn, STORE\&GO Project, 2018. 
a fotovoltaikus kapacitások gyors, 2030-ra 6000 MW-ra való növelése, ezt technikailag támogathatja a P2G-technológia szektorintegrációs funkciója (villamosenergia- és földgázhálózat összekapcsolása). A többlet villamos energia metánná alakítása és tárolása azonban szélesebb társadalmi-gazdasági szempontból is fontos lehet, mivel csökkentheti a földgázimportot, tekintettel arra, hogy a földgázigény körülbelül 80\%-át import fedezi jelenleg. Végül, a közlekedési szektort tekintve, hidrogénből és metánból bioüzemanyagokat vagy „zöld” üzemanyagokat lehet előállítani, amelyek a közlekedésfejlesztési programok részét képezhetik. ${ }^{51}$

\section{KÖVETKEZTETÉSEK}

A tanulmány az innovációs tudáshálózatok felsőoktatásban betöltött szerepét a nemzetközi és a hazai P2G innovációs ökoszisztéma esetén keresztül vizsgálta. Az első kutatási kérdés arra vonatkozott, hogy (1) milyen tudáshálózatokkal lehet jellemezni a fentiekben felvázolt együttmüködéseket a szabályozók, az egyetemek és az ipari szereplők között a nemzetközi és hazai P2G-szegmensben? Az eredmények alapján:

- 1/A: minden jelentősebb nemzetközi P2G-projekt egyetemi és ipari szereplők együttműködése révén jött létre;

- 1/B: a szabályozói, egyetemi és az ipari prioritások és tudásbázisok között vannak átfedések, azonban a vizsgált szegmensben sokféle tudásterület összekapcsolására van szükség, és mindegyik tudásterületen releváns a vállalati és az egyetemi hozzáadott érték is.

Az 1/B következtetés átvezet a második kutatási kérdésre: (2) Hogyan járulhatnak hozzá az egyetemek és a szabályozók az ipari szereplők innovációs teljesítményének növeléséhez és ezzel a társadalmi hasznosság növekedéséhez is?

- 2/A: Egyetemi szempontból, a várakozásokkal némiképp ellentétben, az eredmények arra utaltak, hogy az egyetemi szereplők nem csupán a felfedező tevékenység támogatására képesek (amihez föként alapkutatás társulhat), hanem egy már létező és ipari környezetben is demonstrált technológia kiaknázását is segíthetik a technológia határterületein történő alkalmazott ipari kutatással és fejlesztéssel, ha a felfedezés-kiaknázás dilemmát egyetlen vállalat szemszögéből vizsgáljuk. Ezáltal a központi, társadalmilag értékteremtő potenciállal rendelkező technológia hatékonyabban alkalmazhatóvá válik, így vonzóbb lesz más ipari szereplők számára is.

- 2/B: Szabályozói szempontból az eredmények arra világítottak rá, hogy nem feltétlenül elégséges egyetlen vállalat egyetlen egyetemmel való összekapcsolását ösztönözni az olyan jelentőségű és innovációtartalmú területeken, mint

51 Innovációs és Technológiai Minisztérium: Nemzeti Energiastratégia 2030, kitekintéssel 2040-ig (2020). 13, 14, 20, 42, 50. oldalak. 
a hidrogéngazdaság, a dekarbonizáció és a P2G, hanem sokféle, heterogén tudással rendelkező szereplő összekapcsolása szükséges az innovációs ökoszisztémában.

A következtetéseket a vizsgált eset konkrétumaival kiegészítve, és az elméleti keretrendszer szerint rendszerezve a 4 . ábra mutatja.

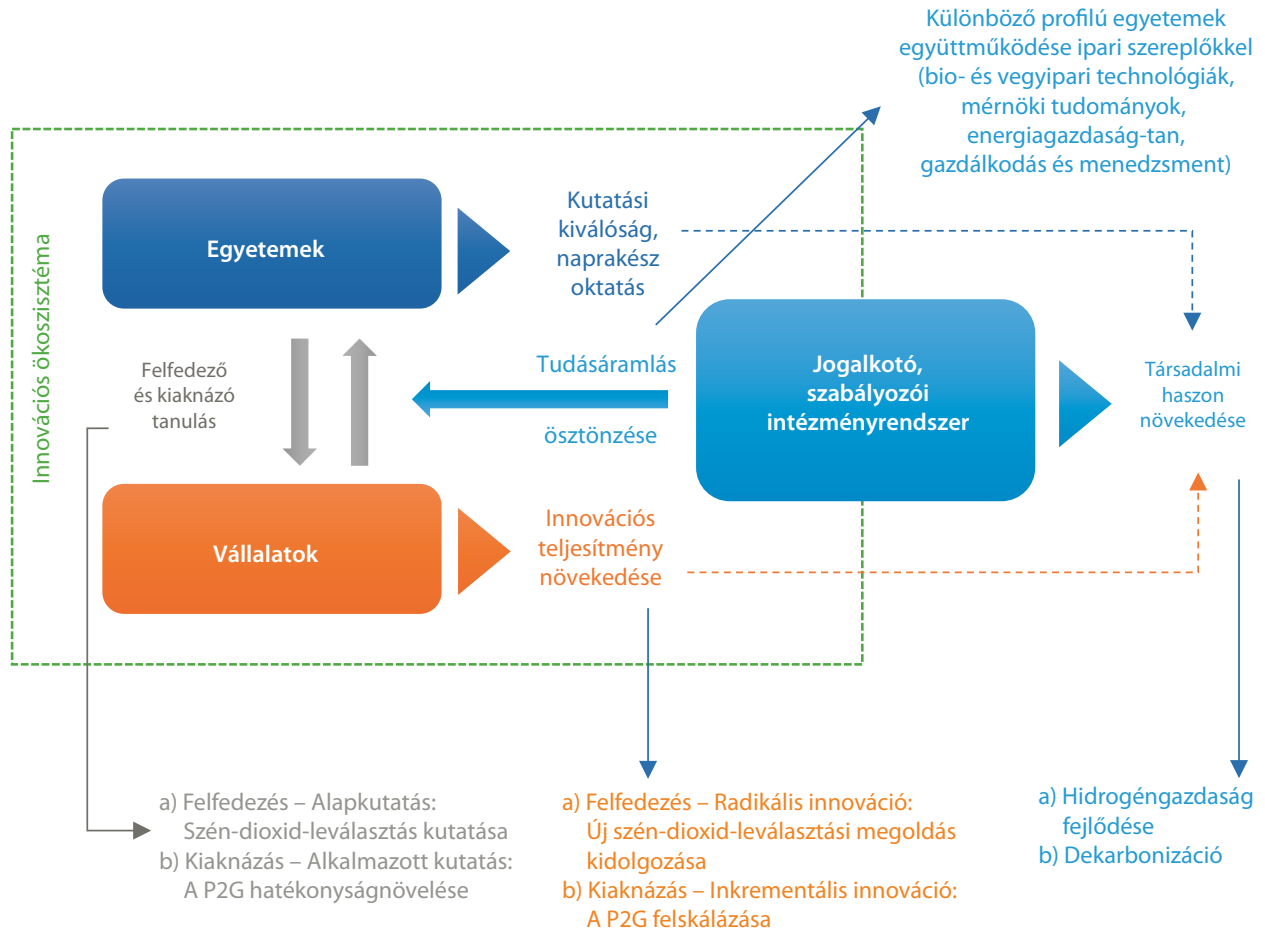

4. ábra • A tanulmány következtetései az elméleti keretrendszer szerint rendszerezve (Forrás: a szerzők szerkesztése)

A kutatás fö korlátja, hogy abduktív módszertanra épült, azaz következtetések nincsenek pozitivista értelemben, statisztikai alapon nyugvó módszerekkel igazolva. A tanulmány specifikus, P2G-fókusza miatt továbbá a felsőoktatási innovációs tudáshálózatok minden aspektusa nem volt lefedhető, például a jövőbeli kutatások az innovációs ökoszisztémában történő működést az innovációs és társadalmi outputok helyett az oktatási eredmények szempontjából vizsgálhatják. 


\section{FELHASZNÁLT IRODALOM}

1. Abe, J. O. - A. P. I. Popoola - E. Ajenifuja - O. M. Popoola: Hydrogen energy, economy and storage: Review and recommendation. International Journal of Hydrogen Energy, 44. (2019), 29. 15072-15086. Online: https://doi.org/10.1016/j.ijhydene.2019.04.068

2. Ahmed, Aram M. - László Kondor - Attila R. Imre: Thermodynamic Efficiency Maximum of Simple Organic Rankine Cycles. Energies, 14. (2021), 2. 307. Online: https://doi.org/10.3390/en14020307

3. Bailera, Manuel - Pilar Lisbona - Begoña Peña - Luis M. Romeo: Integration of Amine Scrubbing and Power to Gas. In Energy Storage. Springer, Cham, 2020. 109135. Online: https://doi.org/10.1007/978-3-030-46527-8_5

4. Bailera, Manuel - Pilar Lisbona - Luis M. Romeo - Sergio Espatolero: Power to Gas Projects Review: Lab, Pilot and Demo Plants for Storing Renewable Energy and $\mathrm{CO}_{2}$. Renewable and Sustainable Energy Reviews, 69. (2017), 292-312. Online: https:// doi.org/10.1016/j.rser.2016.11.130

5. Bailera, Manuel - Pilar Lisbona - Luis M. Romeo - Sergio Espatolero: Power to Gaselectrochemical Industry Hybrid Systems: A Case Study. Applied Energy, 202. (2017), 435-446. Online: https://doi.org/10.1016/j.apenergy.2017.05.177

6. Berényi, László - Zoltán Birkner - Nikolett Deutsch: A Multidimensional Evaluation of Renewable and Nuclear Energy among Higher Education Students. Sustainability, 12. (2020), 4. 1449. Online: https://doi.org/10.3390/su12041449

7. Bixler, R. Patrick - Katherine Lieberknecht - Fernanda Leite - Juliana Felkner - Michael Oden - Stephen M. Richter - Samer Atshan - Alvaro Zilveti - Rachel Thomas: An Observatory Framework for Metropolitan Change: Understanding Urban Social-Ecological-Technical Systems in Texas and Beyond. Sustainability, 11. (2019), 13. 3611. Online: https://doi.org/10.3390/su11133611

8. Blanco, Haji: Report on Full CBA Based on the Relevant Environmental Impact Data. Bonn, STORE\&GO Project, 2018.

9. Boyer, James: Toward an Evolutionary and Sustainability Perspective of the Innovation Ecosystem: Revisiting the Panarchy Model. Sustainability, 12. (2020), 8. 3232. Online: https://doi.org/10.3390/su12083232

10. Burawoy, Michael: The extended case method. Sociological Theory, 16. (1998), 1. 4-33. Online: https://doi.org/10.1111/0735-2751.00040

11. Cao, Xia - Zeyu Xing - Keke Sun: Collaboration Network, Technology Network and Technological Development: A Patent Analysis in the Chinese Green Technological Field of Energy Saving. Foresight, 23. (2020), 1. 33-49. Online: https://doi.org/10.1108/ FS-11-2019-0099

12. Carnegie Mellon University: IECM Technical Documentation: Amine-based PostCombustion $\mathrm{CO}_{2}$ Capture. Pittsburgh, (2018. június). Online: www.cmu.edu/epp/iecm/ documentation/2019Jan_IECM\%20Amine-based\%20CO2\%20Capture.pdf 
13. Corey, Lawrence B. - John R. Mascola - Anthony S. Fauci - Francis S. Collins: A Strategic Approach to COVID-19 Vaccine R\&D. Science, 368. (2020), 6494. 948950. Online: https://doi.org/10.1126/science.abc5312

14. Csedő, Zoltán - Máté Zavarkó: The Role of Inter-Organizational Innovation Networks as Change Drivers in Commercialization of Disruptive Technologies: The Case of Power-to-Gas. International Journal of Sustainable Energy Planning and Management, 28. (2020), 53-70. Online: https://doi.org/10.5278/ijsepm.3388

15. Csedő, Zoltán - Botond Sinóros-Szabó - Máté Zavarkó: Seasonal Energy Storage Potential Assessment of WWTPs with Power-to-Methane Technology. Energies, 13. (2020), 18. 4973. Online: https://doi.org/10.3390/en13184973

16. Csedő, Zoltán - Máté Zavarkó - Balázs Vaszkun - Sára Koczkás: Hydrogen Economy Development Opportunities by Inter-Organizational Digital Knowledge Networks. Sustainability, 13. (2021), 16. 9194. Online: https://doi.org/10.3390/su13169194

17. Deutsche Energie-Agentur - Strategieplatform Power to Gas: Audi e-gas Projekt (2021). Online: www.powertogas.info/projektkarte/audi-e-gas-projekt/

18. Dressel, Sabrina - Annelie Sjölander-Lindqvist - Maria Johansson - Göran Ericsson - Camilla Sandström: Achieving Social and Ecological Outcomes in Collaborative Environmental Governance: Good Examples from Swedish Moose Management. Sustainability, 13. (2021), 4. 2329. Online: https://doi.org/10.3390/ su13042329

19. Duncan, R.: The ambidextrous organization: Designing Dual Structures for Innovation. The management of organization design. In Ralph H. Killman - Louis R. Pondy - Dennis Sleven (szerk.): The Management of Organization. New York, North Holland, 1976. 167-188.

20. Edelmann, Noella - Ines Mergel: Co-Production of Digital Public Services in Austrian Public Administrations. Administrative Sciences, 11. (2021), 1. 22. Online: https://doi. org/10.3390/admsci11010022

21. Electroachea.dk ApS.: Power-to-Gas via Biological Catalysis (P2G-Biocat) - Project final report (2017. április 5.). Online: https://energiforskning.dk/sites/energiforskning. dk/files/slutrapporter/12164_final_report_p2g_biocat.pdf

22. European Commission: A Clean Planet for all. A European strategic long-term vision for a prosperous, modern, competitive and climate neutral economy. $\operatorname{COM}(2018)$ 773 final (2018. november 28.). Online: https://eur-lex.europa.eu/legal-content/EN/ TXT/?uri=CELEX\%3A52018DC0773

23. European Commission - CORDIS: Final Report Summary - HELMETH (Integrated High-Temperature Electrolysis and Methanation for Effective Power to Gas Conversion). 2018. Online: https://cordis.europa.eu/project/rcn/185716/reporting/en

24. European Commission: The European Green Deal - COM(2019) 640 final (2019. december 11.). Online: https://eur-lex.europa.eu/legal-content/EN/TXT/?uri=CELEX\%3A520 19DC0640 
25. European Parliament: The European Green Deal - European Parliament resolution of 15 January 2020 on the European Green Deal [2019/2956(RSP)] 2020. Online: www. europarl.europa.eu/doceo/document/TA-9-2020-0005_EN.html

26. Fiol, C. Marlene - Marjorie Lyles: Organizational Learning. Academy of Management Review, 10. (1985), 4. 803-813. Online: DOI: https://doi.org/10.5465/amr.1985.4279103

27. Ghaib, Karim - Fatima Zahrae Ben-Fares: Power-to-Methane: A State-of-the-Art Review. Renewable and Sustainable Reviews, 81. (2018), 433-446. Online: https:/doi. org/10.1016/j.rser.2017.08.004

28. Glaser, Barney - Anselm Strauss: The Discovery of Grounded theory: Strategies for Qualitative Research. Chicago, Aldine, 1967. Online: www.sxf.uevora.pt/wp-content/ uploads/2013/03/Glaser_1967.pdf

29. Guilera, Jordi - Joan M. Morante - Teresa Andreu: Economic Viability of SNG Production from Power and $\mathrm{CO}_{2}$. Energy Conversion and Management, 162. (2018), 218-224. Online: https://doi.org/10.1016/j.enconman.2018.02.037

30. Haig, Brian D.: An Abductive Theory of Scientific Method. In Method Matters in Psychology. Studies in Applied Philosophy, Epistemology and Rational Ethics. Springer, Cham, 2018. 35-64. Online: https://doi.org/10.1007/978-3-030-01051-5_3

31. IEA Bioenergy: BioPower2Gas in Germany. (2018). Online: www.ieabioenergy.com/ wp-content/uploads/2018/02/2-BioPower2Gas_DE_Final.pdf

32. Istudor, Nicolae - Minodora Ursacescu - Cleopatra Sendroiu - Ioan Radu: Theoretical Framework of Organizational Intelligence: A Managerial Approach to Promote Renewable Energy in Rural Economies. Energies, 9. (2016), 8. 639. Online: https://doi. org/10.3390/en9080639

33. Innovációs és Technológiai Minisztérium: Nemzeti Energiastratégia 2030, kitekintéssel 2040-ig. (2020). Online: https://zoldbusz.hu/files/NE2030.pdf

34. Karlsruhe Institute of Technology: Power-to-Gas with High Efficiency (2018. február 5.). Online: www.helmeth.eu/images/joomlaplates/documents/PI_2018_009_ Power\%20to\%20Gas\%20with\%20High\%20Efficiency.pdf

35. Li, Liu - Chaoying Tang: How Does Inter-Organizational Cooperation Impact Organizations' Scientific Knowledge Generation? Evidence from the Biomass Energy Field. Sustainability, 13. (2021), 1. 191. Online: https://doi.org/10.3390/su13010191

36. Lund, Henrik - Poul A. Østergaard - David Connolly - Iva Ridjan - Brian V. Mathiesen - Frede Hvelplund - Jakob Z. Thellufsen - Peter Sorknæs: Energy Storage and Smart Energy Systems. International Journal of Sustainable Energy Planning and Management, 11. (2016), 3-14. Online: https://doi.org/10.5278/ijsepm.2016.11.21

37. March, James G.: Exploration and Exploitation in Organizational Learning. Organization Science, 2. (1991), 1. 71-87. Online: https://doi.org/10.1287/orsc.2.1.71

38. Mascarenhas, Carla - João J. Ferreira - Carla Marques: University-Industry Cooperation: A Systematic Literature Review and Research Agenda. Science and Public Policy, 45. (2018), 5. 708-718. Online: https://doi.org/10.1093/scipol/scy003

39. Messaoudani, Zine I. - Fotis Rigas - Mahar D. B. Hamid - Che R. C. Hassan: Hazards, Safety and Knowledge Gaps on Hydrogentransmission via Natural Gas Grid: A Critical 
Review. International Journal of Hydrogen Energy, 41. (2016), 39. 17511-17525. Online: https://doi.org/10.1016/j.ijhydene.2016.07.171

40. Millar, Jane - Adrian Demaid - Paul Quintas: Trans-Organizational Innovation: A Framework for Research. Technology Analysis \& Strategic Management, 9. (1997), 4. 399-418. Online: https://doi.org/10.1080/09537329708524294

41. Noussan, Michel - Pier P. Raimondi - Rossana Scita - Manfred Hafner: The Role of Green and Blue Hydrogen in the Energy Transition - A Technological and Geopolitical Perspective. Sustainability, 13. (2021), 1. 298. Online: https://doi.org/10.3390/ su13010298

42. Oosterkamp, P.: Full CBA Analysis of Power-to-Gas in the Context of Various Reference Scenarios. Bonn, STORE\&GO Project, 2018.

43. Palm, Jenny - Magdalena Fallde: What Characterizes a System Builder? The Role of Local Energy Companies in Energy System Transformation. Sustainability, 8. (2016), 3. 256. Online: https://doi.org/10.3390/su8030256

44. Peters, Ralf - Maxana Baltruweit - Thomas Grube - Remzi C. Samsun - Detlef Stolten: A Techno Economic Analysis of the Power to Gas Route. Journal of $\mathrm{CO}_{2}$ Utilization, 34. (2019), 616-634. Online: https://doi.org/10.1016/j.jcou.2019.07.009

45. Pintér, Gábor: The Potential Role of Power-to-Gas Technology Connected to Photovoltaic Power Plants in the Visegrad Countries - A Case Study. Energies, 13. (2020), 23. 6408. Online: https://doi.org/10.3390/en13236408

46. Pintér, Gábor - Henrik Zsiborács - Nóra Hegedűsné Baranyai - András Vincze - Zoltán Birkner: The Economic and Geographical Aspects of the Status of Small-Scale Photovoltaic Systems in Hungary - A Case Study. Energies, 13. (2020), 3489. Online: https://doi.org/10.3390/en13133489

47. Pörzse, Gábor - Zoltán Csedő - Máté Zavarkó: Disruption Potential Assessment of the Power-to-Methane Technology. Energies, 14. (2021), 8. 2297. Online: https://doi. org/10.3390/en14082297

48. RAG Austria AG: Underground Sun Conversion Research Project (2017. március 2.). Online: www.underground-sun-conversion.at/fileadmin/bilder/SUNCONVERSION/ Presseartikel/Press_information_Underground_Sun_Conversion__ENG_2-3-2017_ FINAL.pdf

49. RAG Austria AG: Underground Sun Conversion: Renewable gas produced to store solar and wind power (2018). Online: www.rag-austria.at/fileadmin/bilder/0_NEU_RAG_ Austria_AG/Unternehmen/sunconversion_broschuere_engl_180907_fin.pdf

50. Roberts, Carl: A Conceptual Framework for Quantitative Text Analysis. Quality \& Quantity, 34. (2000), 259-274. Online: https://doi.org/10.1023/A:1004780007748

51. Stanger, Rohan - Terry Wall - Reinhold Spörl - Manoj Paneru - Simon Grathwohl Max Weidmann - Günther Scheffknecht - Denny McDonald - Kari Myöhänen - Jouni Ritvanen - Sirpa Rahiala - Timo Hyppänen - Jan Mletzko - Alfons Kather - Stanley Santos: Oxyfuel Combustion for $\mathrm{CO}_{2}$ Capture in Power Plants. International Journal of Greenhouse Gas Control, 40. (2015), 55-125. Online: https://doi.org/10.1016/j.ijggc. 2015.06.010 
52. Teece, David J.: Explicating Dynamic Capabilities: The Nature and Microfoundations of (Sustainable) Enterprise Performance. Strategic Management Journal, 28. (2007), 13. 1319-1350. Online: https://doi.org/10.1002/smj.640

53. Teece, David J.: Profiting from Technological Innovation: Implications for Integration, Collaboration, Licensing and Public Policy. Research Policy, 15. (1986), 6. 285305. Online: https://doi.org/10.1016/0048-7333(86)90027-2

54. Wang, Xingwei - Liang Guo: How to Promote University Students to Innovative Use Renewable Energy? An Inquiry-Based Learning Course Model. Sustainability, 13. (2021), 3. 1418. Online: https://doi.org/10.3390/su13031418

55. Zavarkó, Máté - Attila R. Imre - Gábor Pörzse - Zoltán Csedő: Past, Present and Near Future: An Overview of Closed, Running and Planned Biomethanation Facilities in Europe. Energies, 14. (2021), 18. 5591. Online: https://doi.org/10.3390/en14185591 
Dr. habil. Csedő Zoltán, PhD a Budapesti Corvinus Egyetem Vezetéstudományi Intézet Vezetés és Szervezés Tanszékének tanszékvezető egyetemi docense. PhDfokozatát 2007-ben szerezte a Budapesti Corvinus Egyetemen, és 2020-ban habilitált a Miskolci Egyetemen. Fő kutatási területei közé tartozik a szervezeti változás és változásvezetés, az innovációmenedzsment, a szervezetközi hálózatok irányítása és a társaságirányítás.

Dr. Pörzse Gábor, PhD a Budapesti Corvinus Egyetem Corvinus Innovációs Kutatóközpontjának vezetője, egyetemi magántanár. PhD-fokozatát 2008-ban szerezte a Semmelweis Egyetemen. Fő kutatási területe a tudomány-, technológia- és innovációpolitika, innováció- és tudománydiplomácia.

Zavarkó Máté, a Budapesti Corvinus Egyetem Vezetéstudományi Intézet Vezetés és Szervezés Tanszékének doktorjelöltje. PhD-tanulmányait a Budapesti Corvinus Egyetem Gazdálkodástani Doktori Iskolájának szervezet- és vezetéselmélet specializációján folytatta, kutatásainak fő témája az energetikai innováció és a szervezeti változások vezetése. 